\title{
A gyermekpszichodráma módszere Magyarországon
}

\author{
Kamasz technikák a módszeren belül
}

\author{
SZEBENI VIOLA \\ JNSZM Pedagógiai Szakszolgálat Jászberényi Tagintézménye, Jászberény
}

(Beérkezett: 2019. február 4.; elfogadva: 2019. július 1.)

Az írásom elméleti háttere a Kende B. Hanna által oktatott gyermekpszichodráma. Ennek a módszernek egyik alappillére a morenói pszichodráma. Részletesen taglalom, melyek azok a technikák, amelyek módosulnak a bemutatott módszerben, melyek a gyermekpszichodráma sajátos koordinátái. Áttekintő tanulmányom célja az elmúlt öt év adatainak az ismertetése: hány ilyen jellegú csoport múködött a jelenlegi munkahelyemen, hány gyerek játszott a csoportokban, milyen korúak a gyerekek és problematikájukat tekintve, milyen tartalmakat lelhetünk fel. Fontosnak tartom a csoportok bemutatásakor azok sajátosságainak a megismertetését: korcsoportokra lebontva, valamint külön hangsúlyozva a különleges csoportok szerveződésekor megismert jellegzetességeket. Ilyen csoport a kamasz csoport. A Nemzetközi Gyermek- és Serdülő pszichodráma Konferencia, Közös nyelv - szimbolikus játék (Budapest, 2018. szeptember 28-30.; Kende Hanna Gyermekpszichodráma Egyesület szervezésében) során megfogalmazódott az Alfons Aichingerrel való együtt gondolkodás és együtt játszás során annak szükségessége, hogy minél szélesebb körben ismertessük a Magyarországon (is) játszott gyermekpszichodrámát, mert nagy a nemzetközi érdeklődés a Kende B. Hanna által oktatott módszer iránt. Ebben a tanulmányban néhány, több konferencián már bemutatott, kamaszokkal jól játszható, gyermekpszichodráma technikát szeretnék részletesen leírni és közkinccsé tenni. A módszer elsajátítása és alkalmazása a tanácsadási kompetenciával jól összeegyeztethetó, többen vannak a módszerben képződött tanácsadó szakpszichológusok, akik a különböző korú gyermekcsoportokkal való foglalkozások során újításokkal, kreatív ötletekkel gazdagítják a gyermekpszichodrámát. Az innovációk szakmai körökben, rendszerint bemutatásra kerülnek. Nemzetközi együttmúködés is fémjelzi az eddigiek során a technikák népszerúsítését. A gyermekpszichodráma terjedését illetóen beszédesek azok az adatok, amelyek arról adnak számot, hogy egyre többen képződnek a módszerben, egyre több gyermekpszichodráma csoport múködik az országban. Jelzem a hiányterületeket, főként a kamasz csoportok hiányát. Gyakran szakambulanciák múködnek csoportterápiás ellátás nélkül. Feltárom az eróforrásokat, azokat a fórumokat, ahol megjelenhet a gyermekpszichodráma, bemutathatjuk technikáinkat, és azt is feltérképezem, ahol ennek még nincs tere. Célom a Kende B. Hanna által megteremtett és évtizedek óta oktatott módszer minél szélesebb körben való terjesztése, valamint olyan, kamaszokkal jól játszható technikák leírása, amelyek a gyakorlatban már használtak, beváltak, népszerúsítésre várnak.

Kulcsszavak: gyermekpszichodráma, pszichodráma technikák, kamasz csoport, nemzetközi érdeklődés

\footnotetext{
* Levelezési cím: Szebeni Viola, JNSZM Pedagógiai Szakszolgálat Jászberényi Tagintézménye, 5100 Jászberény, Nagytemplom utca 1. E-mail: viola.szebeni@gmail.com
} 


\section{Bevezetés}

\subsection{Gyermekpszichodráma Magyarországon}

Ma már évente több mint százhúsz olyan gyermekpszichodráma-csoport indul és múködik a világon, amelyben a Kende B. Hanna adleriánus terapeuta által kidolgozott módszert alkalmazzák. Kende B. Hanna a Société Francaise de Psychanalyse Adlérienne kiképző pszichoterapeutája, a Magyar Individuálpszichológiai Egyesület tiszteletbeli elnöke, és a Magyar Pszichodráma Egyesület szupervizora. Párizsban, a Francia Igazságügyi Minisztérium alkalmazottjaként, az ifjúságvédelemben folytatott pszichológusi tevékenységet és kutatómunkát. Itt fejlesztette ki azt a csoportterápiás, gyermekpszichodráma módszert, amely azóta már széles körben elterjedt.

Ezzel a módszerrel dolgoznak szakemberek Magyarországon, Romániában, Szerbiában, Olaszországban, Franciaországban, Ruandában és Hawai szigetén is voltak csoportok. Egyesület Magyarországon, Olaszországban, Erdélyben (Kolozsváron) és a Vajdaságban (Szabadkán) van, akik kimondottan a Kende B. Hanna-féle gyermekpszichodráma módszert oktatják.

Magyarországon 1997 óta képződnek szakemberek ebben a módszerben. Kezdetben minden résztvevő, lelkesedése és a gyermekekkel való játék nyújtotta új perspektívák felismerése jegyében járt - akár évekig is a Kende B. Hanna által vezetett képzésekre. A 2000 évek elején képződtek a ma már gyermekpszichodráma kiképzők és szupervízorok. Azóta az akkreditációk kérdése is sokat változott. 1997 óta a Magyar Individuálpszichológiai Egyesület keretén belül képződnek a gyermekpszichodramatisták. 2006 óta pedig a Magyar Pszichodráma Egyesület keretein belül is indulnak csoportok a képződni vágyók számára. A Magyar Pszichodráma Egyesületben 2012 óta 5 gyerekdráma asszisztensi csoport és 3 gyerekdráma vezetői csoport végzett. Az egyesület keretein belül Gyermekdráma munkacsoport múködik.

A Nemzetközi Gyermek- és Serdülő pszichodráma Konferencia, Közös nyelv - szimbolikus játék (Budapest, 2018. szeptember 28-30.) a Kende Hanna Gyermekpszichodráma Egyesület szervezésében zajlott. Érdeklődők és tanulni vágyó szakemberek érkeztek Európa tíz országából: Németország, Bulgária, Románia, Oroszország, Olaszország, Franciaország, Lengyelország, Norvégia, Szerbia, Horvátország. Német, angol, francia, orosz, román, olasz nyelven fordították az előadásokat, workshopokat. Ez az esemény nyilvánvalóvá tette, hogy jó gyakorlataink, tapasztalataink túlnőttek az ország határain. Az esemény megerősítette a nemzetközi kapcsolatokat a gyermekdramatisták között; a Kende Hanna Gyermekpszichodráma Egyesület magyarországi képviselői részt vesznek 2019-ben a FEPTO 
(Federation of Psychodrama Training Organisations) szakmai találkozóján, amelyen többek közt a képzési renddel kapcsolatos kérdések kerülnek megvitatásra.

Nemzetközi konferenciák 2 évente szerveződnek, 2020-ban Horvátországban lesz a következő. A konferenciák között FEPTO-munkacsoport találkozók vannak. Ezek 2016-ban kezdődtek és évente kerülnek megrendezésre. Eddigi helyszínek: Berlin, Budapest, Torino, és az idén Cardiff. Ezek a nemzetközi szakmai találkozók alkalmat nyújtanak a különböző országok képviselői számára, hogy szakmai kérdéseket vitassanak meg, és a képzéssel kapcsolatos standardokat dolgozzanak ki.

Nagy feladat hárul a kiképzett gyemekpszichodramatistákra, mert a lelkesedésen, szakmai odaadáson kívül „vázat”, jól áttekinthető képzési rendet, egyértelmú szakmai protokollt kell kidolgozniuk és fejleszteniük ennek a nagyon sokak által gyakorolt és továbbfejlesztett módszernek.

Mivel nem született még egyetlen írás sem arról, hogy kik és miként fejlesztették és fejlesztik ezt a módszert, a teljesség igénye nélkül megpróbálok némi ízelítőt adni a sokszínúségéből. Kezdetben főként bántalmazott és hátrányos helyzetú gyermekeknél alkalmazták. Amint bekerült Magyarországra, a paletta jóval szélesebb lett: használják bármely magatartásprobléma kapcsán, kivéve perverzió és nagyfokú agresszió jelenléte esetében. Különleges csoportok azok, amelyekben például értelmi fogyatékkal élö, hallássérült, daganatos beteg, illetve diabétesszel élő gyerekek játszanak.

A kezdetektől sokat változott az a tér is, ahol a gyermekdráma megvalósítható: léteznek például múzeumi foglalkozások keretén belül szervezett gyermekpszichodráma csoportok és vannak olyanok, amelyek a lovasterápiához kötöttek. Gyakran kombinálják más módszerekkel, például táncés zeneterápiás elemekkel. Mivel nincs átfogó statisztika, nincs pontos számadat arra vonatkozóan, hogy mennyien is vannak a kiképzettek, és hogy jelenleg hány csoport múködik, ezért csak a saját adataimmal szolgálhatok. A saját szakmai életemben, kezdetben 2000-től 2014-ig Hatvanban több száz gyermek játszott, több mint száz csoportban.

A gyermekpszichodráma kiképzői hangsúlyozzák, hogy a módszer elsajátítása és alkalmazása jól összeegyeztethető a tanácsadási kompetenciával, és a módszerben képződött tanácsadó szakpszichológusok a különböző korú gyermekcsoportokkal való foglalkozások során nagyon hatékonyan használhatják tudásukat. A gyermekpszichodráma képzés elvégzése után többen számolnak be arról, hogy gazdagodik a kapcsolódási repertoárjuk a játékhoz, a gyerekekhez. Ennek a módszernek a használata során a közös nyelv, a játék nyelve lesz, és ez öröm vezetókben és gyerekekben - a varázsvilág öröme. 


\subsection{Gyermekpszichodráma a Jászságban}

Az elmúlt öt évben, a Jász-Nagykun-Szolnok Megyei Pedagógiai Szakszolgálat Jászberényi Tagintézményében dolgozom. A nevelési tanácsadás szakszolgálati feladatellátáshoz kapcsolódóan a Jászberényi Tagintézményben 2014 óta szervezünk gyermekpszichodráma csoportokat óvodás gyermekek, iskolás- és serdülőkorú tanulók részére, valamint szülő-gyermek csoportokat is. Összesen 58 pszichodráma csoportot indítottunk 350 gyermek, 7 pedagógus, és 5 külső szakember (könyvtáros, múzeumpedagógus, népmúvészek) bevonásával. A csoportok jellegét tekintve a következő csoportok múködtek:

Korosztályok szerint szervezett csoportok, óvodás, 1-2. osztályos, 3-4. osztályos, 5-6. osztályos, 7-8. osztályos, és gimnazista, illetve szakközép-, szakiskolás tanulók számára múködtetett csoportok. A kiskamasz csoportok 11-13 évesekból szerveződtek, a kamasz csoportok 14-16 évesekből álltak, az ifjúsági csoportok 17-21 éveseket foglaltak magukba.

Sajátos múfaja az itt múködő csoportoknak az anya-gyerek gyermekpszichodráma csoport (kizárólag 5-6 évesek számára szervezettek), valamint az olyan szülócsoport, amelyben a szülők gyermekeikkel megtapasztalható nevelési problémáikat a gyermekpszichodráma módszere által próbálják megélni és megoldani.

A csoportok múhelyszerúen múködnek, általában 15 alkalommal találkozunk. Múhelyjellegét az adja, hogy a találkozások alatt fóként pszichodrámát játszunk, de minden csoport életében volt legalább három alkalom, amikor különböző helyszíneken - például múzeumban, könyvtárban - egy meghívott szakember (népi iparmúvész, múzeumpedagógus, gyermekkönyvtáros) tartott foglalkozást.

\section{Mi a gyermekpszichodráma?}

\subsection{A morenoi módszer változásai \\ a gyermekpszichodrámán belül}

Kende B. Hanna egy 2012-es interjúban adott megfogalmazását idézve: „A gyerek-pszichodráma egy csoportterápiás módszer, amely a közös szerepjátékon, a gyerekek képzeletvilágának és kreativitásának mozgósításán keresztül fejti ki terápiás hatását. A gyermekjátékdráma játékban, játékkal, játék által gyógyít, fejleszt. Ha nem félnénk az általánosítástól, azt mondhatnánk, hogy a legtöbb pszichoterápiát igénylő gyerek közös jellegzetessége a bizalmatlanság, az önbizalom hiánya: érzelmi kapcsolatteremtési nehézségek jellemzik, magukat értéktelennek érzik, lebecsülik, nem bíznak saját ké- 
pességeikben, nincs pozitív énképük. Bizonyos típusú gyermekpatológia, elsősorban a szociálisan veszélyeztetett, vagy a pszichoszomatikus panaszokat felmutató, a magatartásproblémás, a szórakozott, a rosszul teljesító bár jóképességú vagy iskolában elutasított gyerekek egy részének érzelmi problematikája nehezen megközelíthető a klasszikus pszichoterápia keretei között." ${ }^{1}$

A gyermekpszichodráma a morenói pszichodrámából (Moreno, 1969) alakult ki. Számos morenói technika átalakult a gyermekekkel való együttjátszás során (Kende, 2000). A gyermekek mesés, fantasztikus történeteket játszanak el, nem valóságos élményeiket idézik fel, mert az számukra nagyon megterhelő lenne. Az ő esetükben nem az a cél, hogy szembesítsük óket a lelki zavaraik kiváltó okaival, hanem, hogy olyan szerepeket játszhassanak el, amelyekben az elfojtott spontaneitásuk, kreativitásuk kifejezésre juthat. A mozgósított képzelőerő által hatni kezd a szimbolizmus ereje.

Ezzel a módszerrel dolgozó dramatisták nem értelmeznek, a gyermek játékát követően nincs interpretáció. A gyermekpszichodráma-vezető szerepe az, hogy együtt játsszon a gyerekkel egy olyan csodavilágban, ahol a gyermek megismerheti és kiteljesítheti vágyait, addig rejtett képességei által. Olyan életérzések - győzelmek és sikerek - részese lehet, amelyek arra predesztinálják, hogy a mindennapok harcaiban is nyertes lehet. A csoport előtt - és részvételével - megnyert csaták megváltoztatják a gyermek önképét, visszanyeri önbecsülését, és ezt kiviszi a dráma falain túlra, hadd lássa a világ.

A gyermekpszichodráma során nem használatosak az olyan technikák, amelyeket a felnőtt pszichodráma sikeresen beépít a csoporttörténésekbe. Nem használatos a monológ, a belsó hang (a szereplő háta mögé állva, a csoporttagok kifejezik, mit érezhet az adott helyzetben), a szerepcsere, és sok más olyan eljárás, amely távol áll a gyermek önmegvalósítását segítő, spontán, autonóm önkifejezését életre hívó játékélménytől.

\subsection{A gyermekpszichodráma sajátos koordinátái}

\subsubsection{Módszer az elidegenedés ellen}

A 21. század posztmodern valóságában nagyon helytálló módszer a gyermekpszichodráma. A posztmodern kor jellemzője a bizalmatlanság és a bi-

\footnotetext{
1 A gyermekpszichodráma egy csoportterápiás módszer. Beszélgetés Kende B. Hannával. Letöltve: 2012. 10. 07-én: http:/ / www.szombat.org/kultura-muveszetek/4682-a-gyerek-pszichodramaegy-csoportterapias-modszer
} 
zonytalanság, megkérdőjelezi a szubjektum önazonosságát és az egységes, abszolút világmagyarázó elvek létét.

Ha ez a tanulmány csak öt évvel is korábban íródik, valószínúleg nem hangsúlyozza azt, hogy „posztmodern”. A gyerekpszichodráma az adott kor tükre lesz mindig. Így az elmúlt öt évben a gyermekek meséiben kidomborodott, mindent eluralt ez utóbbi létjogosultsága: semmi nem az, ami; nincs kimondottan gonosz és nincs kimondottan jóságos; lelketlen gépek is lélekkel teli, érző lények lehetnek, látszólag kedves kis lények is ellened fordulhatnak; nem vagy ura magadnak, megszállhatnak a szimbióták és csak úgy el is mehetnek; létrehozhatsz virtuális barátokat, akik nagyon hasonlítanak ellenségeidre, hát vigyázz!

A gyermekek meséiben kevésbé lelhetóek fel a hagyományos elemek, például a rossz és jó polarizáltsága, a hagyományos szereplők (tündér, boszorkány, vitéz).

Hogy ebből csak nihilizmus lehet, azon nincs mit csodálkozni, hiszen „amikor az ember egyre inkább a kvantitatív világ felé [fordul], akkor voltaképpen a semmi felé fordul. Mert ahogy az ember a szellemet elveszítve a lelket tartotta meg, amelynek még voltak bizonyos szellemi tulajdonságai, majd csak a testet tartotta meg, amelynek vannak még bizonyos lelki tulajdonságai, lassan eljut a semmihez, aminek lesznek még bizonyos testi tulajdonságai" (Buji, 2008).

Közös meséléseink által az összezavarodott értékek elkezdenek tisztázódni, lassan körvonalazódik az, amit le kell győzni (legyen az robot, ragadozó, zombi, bármi), de gyakran előzőleg kipróbálja, eljátssza, milyen az. Sehol nem teheti ezt meg, csak a dráma által felajánlott térben, abban a biztonságban, amit a csoport elfogadó légköre nyújt.

A gyermekpszichodráma során nagyon kevés, de izgalmassá tehetó eszköz áll a csoport rendelkezésére: kopott kalapok, sálak, jelmezekké alakítható ruhadarabok. Nem ezek miatt jár drámára a gyerek, hanem azért, amit ezekkel tehet a többiek szeme láttára, füle hallatára: saját akaratából, a társak segítségével, eltelve azzal az élménnyel, hogy milyen nagyszerú ötletei adódtak.

A mai kor gyermekei, az őket körülvevő légkörben szomjazzák azt, amit ezáltal a módszer által közösen megteremtünk. Olyan személyközi tér teremtődik, amelyben egyenrangúak a felnőttekkel, de tökéletesen tudják és érzik, hogy ki viszi a puskát. A vadász viszi. A felnőtt játszik és játékában vigyáz a gyermekre. Teret ad ahhoz a nagyszerú feladathoz, ami a gyermek önteremtése. A gyermekeknek megvannak az öngyógyító képességeik, ehhez fel kell ébreszteni a kreativitásukat, meg kell adni az alkotás lehetőségét. Az általuk teremtett mesékben, történetekben szörnyekkel, vasemberekkel, jégsárkányokkal küzdenek meg sikeresen, kiszabadulnak a fogsá- 
gukból, megmenekülnek az elemek özönéból. Mindez egy jól körvonalazott játéktérben történik:

„Winnicott megközelítésében a játéktér (ideérti a pszichoterápia és a pszichoanalízis terét is) legfőbb jellegzetessége, hogy sem a tudattalanhoz, sem a valósághoz nem tartozik. Olyan sajátos világ ez, ahol a pszichoterapeuta a klienssel találkozik... Szeretnék egy fontos szempontot hozzátenni ehhez a szemlélethez, saját játékterápiás vagy pszichodramatikus tapasztalatunknak egy fontos tanulságát. Ez a potenciális tér valóban különleges, sehol másutt nem létező közeg, amelyben kibontakozhat az alanynak (itt a gyereknek) a kreativitáson túlmutató önteremtő képessége, de hangsúlyozni szeretném: bár ez a potenciális tér a gyerek és a pszichoterapeuta, a gyerekek és a csoportdramatisták közös alkotása, kialakításába a gyerek és a felnőtt nem egyenlő mértékben vesz részt. A potenciális tér elsősorban a gyerek kreativitását világteremtő képességét mozgósítja. A dramatista szerepe egyrészt a gyermek kreativitását kiváltó légkör biztosítása, másrészt a gyermek fantáziavilágában való részvétel, úgy, hogy ne akadályozza, hanem ösztönözze a gyereket a továbbhaladásra a maga választotta úton, és arra, hogy kreativitását a maga teljes erejében kibontakoztassa" (Kende, 2000, 65. o.).

A posztmodern kor gyermekei, posztmodern problémákkal és tartalmakkal érkeznek a csoportra. Szúkítve a kört, nemcsak a kor nehezíti helyzetüket, de általában félnek a felnőttektôl, sőt gyakran a gyerekektól is. Rossz tapasztalataik vannak a csoportléttel kapcsolatban. Mivel közösségi értékeket nem nagyon tapasztaltak meg, ez lesz az a tér, ahol meg kell történnie a korrekciónak. Az önmagukról alkotott képük megváltoztatása a cél.

\subsubsection{Az alapvető lelki szükségletek}

Alfons Aichinger, a 2018. szeptember 28-án megrendezett Nemzetközi Gyermek- és Serdülő pszichodráma Konferencián, előadásában arról beszélt, miként áll a gyermekpszichodráma, a gyermek alapvető pszichológiai szükségletei kielégítésének szolgálatában. „Kutatások és vizsgálatok bizonyítják (...) a szoros összefüggést az alapvető lelki szükségletek kielégítetlensége és a pszichológiai egészség között" (Aichinger, 2018). Klaus Grawe (2004) a svájci pszichoterapeuta professzor a felnőttek pszichológiai lelki egészségét és kezelését szolgáló könyvében bemutatja alapvető szükségletekre vonatkozó modelljét, amelyet Alfons Aichinger adaptált a gyermekekkel és fiatalkorúakkal való munkára. Ezek a szükségletek: az énerő/hatóerő, a kapcsolódás szükséglete, az önértékelés/önbizalom növelésének alapszükséglete, és az örömérzet iránti vágy. 


\section{Kamasz technikák a gyermekpszichodrámában}

\subsection{A módszerek eddig történt bemutatásának fórumai}

Az itt következő módszereket fóként olyan csoportokkal dolgoztam ki (általában kiskamasz vagy kamasz csoportokkal), akiknél nagyon nagy ellenállás mutatkozott a saját magukkal végzendó pszichológiai munkával kapcsolatban. Olyan korban voltak, hogy játszani "csak úgy" nem akaródzott, de a konkrét-, számukra sérülést okozó eseményeket megismételni a trauma megismétlését jelentette volna. Ezt feltétlenül el kell kerülni, lévén, hogy ők még gyerekek, és ezért a trauma megismétlése elakadást okozhat a személyiségfejlódésükben.

Az itt bemutatott eljárások, technikák nagy része saját elképzelés, valamennyit több csoportnál kipróbáltam és szakmai körökben több alkalommal bemutattam.

Ilyen módszer a Faépités. Ezt 2005 szeptemberében mutattam be az Individuál Pszichológiai Társaság egyik ülésén.

A Folt-technikát 2005. május 6-7-én a Pszichoterápia és tanácsadás a társadalmi változásban konferencián mutattam be „Interaktív csoporttechnika kamaszokkal" címmel. Ezt a módszert leírtam a Pszichoterápia folyóirat által meghirdetett „Kényszermegoldásokból kincsek: Mit hozhatunk ki a körülmények okozta nehézségekből? címú pályázatra „Foltokból valóság" címmel (Szebeni, 2016). 2018-ban a Nemzetközi Gyermek- és Serdülő Pszichodráma Konferencián külföldi kollégák számára mutattam be.

Azt a technikát, amelyben a csoporttagok különbözö tárgyakká és állatokká varázsolják egymást, majd ezek közül minden csoporttag kiválasztja azt a varázslatot, ami számára a legtöbbet mond, a 2008. november 14-16-án Kolozsváron megtartott első Nemzeti Pszichodráma Konferencián mutattam be, amit „De la Izvor la Izvor”, Forrástól forrásig címmel tartottak.

A Kriksz-kraksz módszert a Kende Hanna Gyermekpszichodráma Egyesület által 2017. szeptember 29-30-án szervezett Gyermekpszichodráma Találkozón ismertettem workshop formájában, a találkozó címe: Értékek mentén - módszertani újdonságok a gyermekpszichodrámában.

2017. szeptember 26-án szakmai bemutatót tartottam a JNSZMPSZ Jászberényi Tagintézmény képviselőjeként az iskola pszichológia munkaközösség találkozóján.

2017. október 20-21. Kolozsváron tartottam képzést a gyermekpszichodráma szakképzett vezetői számára (Asociatia de Psichodrama pentru Copii si Adolescenti „Kende Hanna” Cluj-Napoca; APCAKH). Ekkor, kétnapos képzés keretén belül több módszerdemonstráció is történt.

2018. május 11-én a Fejér Megyei Pedagógiai Szakszolgálat Sárbogárdon szerveződő konferenciáján workshop vezetésére kaptam meghívást. A kon- 
ferencia címe: Coping, mindfullness - a szorongás legyőzhetó! Ezen a workshopon gyermekpszichodráma módszerbemutatót tartottam. A résztvevők, szám szerint 25 kolléga kipróbálhatta az általam kidolgozott Kamasz krikszkraksz módszerét.

A JNSZMPSZ iskolapszichológia munkaközösség találkozóján, 2018. október 3-án a kamaszokkal végezhető gyakorlatokat mutattam be, sajátélményú tapasztalatszerzést nyújtottam a jelenlévóknek.

2018. november 17-én részt vettem a III. Pszichológiai Tanácsadás Konferencián (PSZITA), a tanácsadó szakpszichológusok számára rendszeresen, évenkénti szakmai konferencián, worshop-ot tartottam, Kriksz-kraksz módszer címmel.

\subsection{A kamasztechnikák néhány jellemzője}

A módszerek közül többet használnak általam is kiképzett gyermekdramatisták. Ezek a technikák, az „itt és most”-ban született helyzetgyakorlatok. Olyan ráhangoló gyakorlatok, amelyek a gyermekcsoportok sajátosságaihoz igazodva születnek meg.

A gyakorlatban jól múködnek, beindítják a gyermekek szimbolikus gondolkodását és teret adnak számukra ahhoz, hogy kifejezzék aktuális életérzéseiket, akkor is, ha azok negatívak, anélkül, hogy bármiféle szankcióban részesülnének, és ezek szimbolikus kifejeződése révén búntudat sem követi játékukat. A „mintha világa” éppen elég biztonságos és gazdag lehetőséget nyújtó ahhoz, hogy a bántalmazást, az agressziót, az elutasítást megfogalmazhassák általa és többlettartalommal telítve megváltoztathassák.

A munka legszebb része a találkozások sorozata, amikor alkalomról alkalomra eljönnek a gyerekek, nagyon kevés hiányzással, rendszerint várják és megdolgoznak a csodáért, aminek megteremtőik ók maguk.

Az általam elképzelt- és bevetett módszerekben a következő tagolás érvényesül: első lépés az alkotás, majd a verbalizálás, ezt követi a dramatizálás.

Az alkotás esetében, minél elementárisabb a technika, annál jobb. Lehet firkálni, vágni, tépni, vésni stb. A végtermék mindenképpen nyerjen értelmet, hogy a csoport megfogalmazhassa a gondolatait vele kapcsolatban, és az alkotó is elmondhassa a saját történetét.

A verbális megfogalmazás a következő lépés, a kötelezően követendő algoritmus szerint: először a csoporttársak mondják el gondolataikat a társuk alkotásáról, majd az alkotó fogalmazza meg a történetét, végül kérdéseket lehet feltenni az alkotónak, és utoljára ő kérdezhet azzal kapcsolatban, amit az ő múvéról mondtak. 
Olyan módszerek használatára törekedtem, amelyek által a gyermekek úgy verbális, mint nonverbális szinten megnyilvánulhatnak. Mivel a kétféle kifejezésmód más-más fejlettségi szinten nyilvánul meg a különböző egyéneknél, az adott módszerek lehetőséget teremtenek arra, hogy az egyik résztvevő által bemutatott, a csoport elé kitett tartalmat a többiek, a jobban fogalmazók, szavakba öntsék. Nagy lehetőség ez azoknak, akik nyelvi gátak, vagy éppen az indulatok, érzelmek intenzitása miatt nem tudnák szóban elmondani, amit megalkottak.

Ezt követi a szerepjáték, a gyermekpszichodráma szerveződése szerint, eljátsszák a történetet a kiadott, vagy a választott szerepekkel. Nincs belső hang, tükrözés, szerepcsere. A játék végén a megbeszélés csak arról szól, hogy milyen volt azt a szerepet játszani, mi volt a jó, vagy a rossz abban a szerepben.

Célom, hogy ezek a módszerek megkönnyítsék a szimbólumalkotást, a többlettartalom megszületését, hogy behívják a kiskamaszokat és kamaszokat a játéktérbe, alkotásra serkentsék őket és megajándékozzák általuk magukat és egymást egy negatív feszültségektől kevésbé terhes, spontenaitásra, alkotásra képes életérzéssel. Megtanulják, hogy ki lehet fejezni és ki is kell fejezni a bennük lévő érzéseket, mert akkor azok megszelídíthetőek. Ugyanakkor a felkínált technikák kibővítik az élményanyagaikat, ismereteiket egymásról, az anyagról, a használhatóságukról és kibővül általuk az életnek az a mezsgyéje is, amit bejárhatnak.

A csoportfoglalkozásokon a csoporttagok felismerik, „milyen az, amikor együttmúködnek a gyerekek, amikor segítik a másikat. Van egy fogalom, amely a nyugati pszichológiában nagyon divatossá vált. Ez a resilience. Magyarul úgy határozhatnánk meg, hogy jóvá-tétel illetve: jóvátétel. Ez jelenti egyrészt az elszenvedett sérelmek jóvátételét, másrészt jóvá tenni a rossznak mondott, a magát rossznak tartó gyereket is. Nemcsak az fontos tehát, hogy a gyerek túlélje, feldolgozza a traumatikus élményeit, hanem az is, hogy közben megtanulja, ő is lehet jó. Ö is lehet szerethetô." ${ }^{2}$

\subsection{Kamaszokkal alkalmazható technikák}

A következő részekben leírom a technikákat és egy-egy példát adok a kamaszok játékából arra, hogy hogyan fejezték ki ők maguk alkotásaik, történeteik révén aktuális életérzéseiket.

2 Senki sem születik agresszívnek. Interjú Kende B. Hannával. Letöltve: 2017. 12. 26-án: https:/ / hogyanmondjamelneked.hu/transzgeneracios-trauma/2017/12/26/senki-sem-szuletikagresszivnek 
A bemutatott módszerek arra hivatottak, hogy a kamaszok könnyebben fogalmazzák meg mondandójukat. Abban segíti óket, hogy kifejezzék aktuális életérzéseiket és ezeket játékba fordítsák, lejátsszák. A drámavezetók beavatkozásai ugyanazok, mint a gyermekpszichodráma során. Mindkét drámavezető együtt játszik a kamaszokkal. Néhány játékszervezési különbség azonban adódik az eljátszás során. Ezek a következők.

A játékot előkészitó fázisban a kamaszok nagyobb gonddal és - érettebbek, erősebbek lévén - több odafigyeléssel és energiabevetéssel dolgoznak a történet helyszíneinek a kidolgozásán. Például padokat, székeket építenek öszsze, bunkereket, barlangokat alkotnak kartonokból, dobozokból. Nagy gonddal készítik jelmezeiket is, használhatnak biztosítótúket, kapcsokat, ollót, zsinórokat.

Az akció során gyakrabban használják a sötétítőket, fényeket (oltják, gyújtják a villanyokat). Az eljátszás során a „mintha világa” teljes értékúen megmarad, de vannak szituációk, amikor az előzetes megbeszélés során megegyezünk, hogy milyen formában tehetik kifejezőbbé a játékot. Például, ha bezárták a foglyot, akkor az tényleg csak akkor jöhet ki, ha minden egyes elé állított "akadályt” (bútordarabot: pl. kisszékek, asztalok; botok, dobozok) sorban félre tud állítani. Akkor is, ha ez fizikálisan nehéz. További példa, hogy amikor valaki az „életet adó óriási hegyet” játssza, akkor felállhat az íróasztalra. Gyakori, hogy a telefonjukról zenei aláfestést keresnek a jelenetekhez.

A lezáró körben rendszerint nemcsak arra a kérdésre felelnek, hogy mi volt a jó és mi volt a rossz a saját szerepük megélése során, hanem arra is, hogy melyik szerep volt az, amelyiket szívesen eljátszanák, ha újra sor kerülne a drámajátékra. Ennek a kérdésnek a célja az, hogy az egymásra figyelést erősítse, és a következő szerepet előkészítse.

\subsubsection{Faépités}

A kérésem az, hogy az elóttük tornyosuló eszközökből (gurigák, kartonok, múanyag flakonok, színes papírok, pálcikák, rongyok és sok minden egyéb) építsen minden csoporttag egy saját Fát. Ehhez bármit felhasználhattak a nagyon gazdag kelléktárból, és bármit átalakíthatnak, vághatnak, ragaszthatnak. Annyit kellett kezdetben leszögezniük, hogy a terem mely részében, szegletében akarják a fájukat felállítani és rögzítettük körbejárva a határt is, meddig az övék az „építési terület”. Miután fájukat felépítették, megkérdeztem, hogy ki az első, aki szeretné, ha az övéről beszélnénk és ezt követően a Fa köré ültünk. Minden alkalommal, amikor alkotásaikat befejezik a következő sorrendben zajlanak a csoportesemények: 
Megkérdezem, hogy ki szeretné, ha elsőnek az ő alkotásával foglalkoznánk.

Ezt követően azt a bizonyos alkotást körbeüljük, fókuszba kerül.

A csoport tagjai elmondják benyomásaikat, gondolataikat az illető múröl.

Megkérdezzük az alkotót, hogy ő mit akart ábrázolni, és hagyjuk szabadon beszélni alkotásáról.

Kérdéseket tehetünk fel neki és ő is nekünk, ha a csoportból valaki gondolatára rá akar kérdezni azzal kapcsolatban, amit az alkotásról mondott.

Mindannyian címet adunk a kirakott múnek.

Az a csoporttag, akinek az alkotása ily módon megbeszélésre került, kijelöli a következőt, amelyik számára érdekes és szeretne arról minél többet megtudni.

Ezt követóen a következő csoporttagnál ugyanígy járunk el.

A Fa építésekor, például ilyen és ehhez hasonló történetek születtek. (Kezdetben mindig a csoport megjegyzései vannak feltüntetve, majd az, amit az alkotó maga mondott.)

A csoporttagok észrevételei: „Fegyvernek néz ki." „Kék fa.” „Ez olyan, mint egy tótágas robot.” „Ágyús-fa.” „Olyan, mint egy tévé-rádióadó.” „Három ága van."

Egy gyermek saját története: Én vagyok Naruttó, harcos vagyok, sokat zabálok tésztát, gombócot. Mikor támadnak, megfogom ezt a fát, kiemelem és fejbe vágom vele. Kakasi támadott meg, úgy, hogy megette elólem a levest. Harcoltunk és nyertem. Utána megtámadtam Fekete Pákót és nyertem. Kakasi azért támadott meg, mert kell neki ez, mert nem tud építeni, ellopja. Én csinálnék másikat. Ha ellopják, mindig visszaszerzem, és mindig ellopja.

A csoport tagjai ötleteket adtak hogyan győzze le Kakasit. „Tegyél a kávéjába hashajtót.” "Gáncsold el.” „Ketrecbe kell zárni.” „Legjobb megharapni."

A rövid narrációban egy szorongó gyerek azt fejezi ki, hogy tőle mindig elvesznek valamit (bizalmat, nyugalmat, bármit) és ő azt mindig vissza kell, hogy szerezze. Agresszióját nyíltan kifejezi, miként azt is, hogy neki feltétlenül harcolnia kell. Állandó hadakozás színtere az ó élete. Mindenki komolyan veszi. Fontos, amit mond. Innen indul a dráma kezdetén, ebból az állapotból mozdul ki, és talál kompromisszumlehetőségeket a környezetében.

\subsubsection{Folt-technika}

A Folt-technika a következő lépésekből áll. Minden lépés egy-egy alkalom.

Nagy mennyiségú festéket kapnak, temperát, vízfestéket, ujjfestéket (kamaszok és kiskamaszok általában nem szeretik használni az ujjfestéket). 
Azt az utasítást kapják, hogy csomagoló papírra vigyék fel ezt a festéket foltok formájában. Ne maradjon a papíron fehér terület.

Következő találkozásra a megszáradt festékek foltjait körberajzolják fekete filctollal, olyan formákat keresve melyeket meg tudnak nevezni. Néhány példa a körberajzolt, megnevezett formákból: bumeráng, malacláb, csiga, láng, gekko, dagadt krokodil, kettős tornádó, tengeri uborka, bárd, Pom-pom, száj.

A körberajzolt foltokat közkinccsé tesszük, vagyis bárki kivághatja bármelyiket, függetlenül attól, hogy ki rajzolta. Ha valaki mégis ragaszkodik az általa talált folthoz, akkor azt ó vághatja ki és meg is tarthatja, mert ezeket a kivágott foltokat mindenki egy külön borítékba gyújti. A saját borítékára mindenki ráírja a nevét.

Következő alkalommal mindenki megkapja a borítékját és egy A3-as lapot vagy választhat színes kartont is. Az a feladata, hogy az összegyújtött foltokból készítsen egy kompozíciót, egy olyan múvet, amelynél ragasztással felhasználja az adott foltokat és használhat festéket, filctollat, zsírkrétát, színes ceruzákat ahhoz, hogy a hézagokat kitöltse. Így ha a felragasztott foltok között szeretne valamit ábrázolni, keretet, hátteret tud adni az alkotásának.

Minden egyes múvet a fentiekben ismertetett módon dolgozzuk fel a továbbiakban.

Egy folt-technika-mese: Az alkotója 15 éves kamasz. Kipróbálta a drogot. A foltokból megalkotta a következőket: egy nagyon nagyfejú, torz ember, egy kő és a lába előtt fúszálak. A saját története arról szól, hogy ezt az embert fóbe ütötte a kő, ezért botlott meg a fúben. Csillagokat lát. A szimbólumok szintjén elmondta a megélt élményét, így volt megosztható. Amiról, akár virágnyelven is, de beszélni lehet, az a továbbiakban könnyebben feldolgozható.

\subsubsection{Félig kész rajzok kiegészítése}

Sok összegyújtött, félig kész, különböző korú gyerekek által készített rajz marad a váróteremben. Ezek nagyon kedves, olykor ijesztő, elhagyott múvek. Nincsenek befejezve, esetenként csak egy foltot, vagy valamilyen tárgyat, alakot ábrázolnak. Főként ceruzával, de akad olyan is, amelyik zsírkrétával vagy más technikával készült. A csoport elé szétszórva kitettem kb. 30-40 ilyen rajzot, és arra kértem a résztvevőket, hogy válasszanak egyet, amelyikből újat tudnának alkotni, azáltal, hogy kiegészítik a meglévő nyomokat. Próbálják magukban megindokolni és később a csoportnak is, hogy miért azt választották. Csendes foglalkozás következett, amikor a kitett anyagokkal - tempera, vízfesték, színes ceruzák, zsírkréták, ragasztó, színes papír, stb. - kiegészítették, kijavították, befejezték, teljessé tették az általuk kiválasztott kompozíciót. 
Egy mese a félig kész rajzok kiegészítése nyomán: „Volt egy báb és lógott a fán. Kikelt belőle egy pillangó. A nap megszárította a szárnyát és repülni kezdett. De jött egy béka és azt mondta: Bekaplak! Már ugrott volna, a hoszszú nyelvét kiöltötte, amikor jött a gólya és bekapta. A lepke kinevette, kárörvendően, és elrepült a naplementébe, a többi lepkéhez." Ennek a történetnek az eljátszása során a mesélő kamasz lett a legszebb, a legfürgébb, a legszabadabb - a Lepke; és ennél több lehetőséget nem is adhatott neki a csoport, ahova megérkezett ezzel a történettel.

\subsubsection{Kamasz kriksz-kraksz}

Ez eredetileg a winnicotti firka-játék (squiggle game) (Winnicott, 1999) felhasználása, annak átalakítása, illetve alkalmazása csoporttechnikaként.

A nehezen beinduló kamaszcsoportok számára a módosított Winnicott firka-technika onnan indul el, ahol ő tart: firka, vagyis tartalmak, amelyek elbújtak, dekódolni kell. Célja: káoszból rendet alkotni, vagy legalábbis nyugvópontokon megpihenni; megosztani a gondolati tartalmakat nagyobb kockázat nélkül; megtudni, hogy „mások” mit is gondolnak „rólam”, anélkül, hogy kritika hangzana el.

A közös játék fő jellemzője, hogy minden résztvevő saját döntése szerint választhat, variálhat. Közös lendület létrehozása valósul meg, amely azokat is elragadja, akik különben általában nem gondolnak "semmiről semmit”. Egymást győzik meg a tevékenység során arról, hogy milyen sok mindent is gondolnak egyszerre, sokszor egyformán. Nagyon fontos, hogy abból induljunk ki, ami az ő tartalmaik. Ezek a tartalmak - amint azt tudjuk - a kamaszkorban elég kuszák, képlékenyek, ez is-az is lehet, szorongással telítettek. A játék menete a következő:

Az első utasítás: (Minden csoporttag egy színes ceruzát választ, végig azt használja.) „Egy írólapra firkáljatok valamit mérgesen.” (Négyen ülnek egy asztalnál.) Négy írólapra firkálnak (mindenki a magáéra), koppintásig. Az a fontos, hogy mindenki csak a saját írólapjára firkáljon, mert majd valamit ki kell venni ezekból az ábrákból. Négyszer ismételjük meg a felhívást, hogy firkáljon a lapra, mindig más-más lapra. Minden esetben más-más utasítást adunk. Ez lehet például, hogy "firkálj bal kézzel”, vagy „firkálj két kézzel”, vagy valamilyen érzést hívunk.

Második utasítás: „Tegyük az asztal közepére a firkáinkat!” A közösbe dobjuk be (az asztal közepére tesszük), vagyis a kamasz azon igénye érvényesül, hogy beleolvadhat az alkotása a többiekébe. Közkinccsé teheti, amit firkált már nem az övé, hanem mindenkié, és mindenkié az övé is.

Harmadik utasítás: „Egészítsétek ki a firkákat. Szemléljétek meg valamennyit, amelyikbe beleláttok valamit, azt tegyétek értelmes rajzzá. Ezt 
követően tegyétek vissza az asztal közepére." Ez a lépés azt az igényt szolgálja ki, hogy kontroll nélkül, saját indíttatásából azt a firkát egészíti ki, amit akar (nemcsak a sajátját, mert az már nem saját, közös lett a csoporttal, azáltal, hogy bármelyiket kiegészítheti). Nem kell nógatni őket, mert mindegyikük érdekesnek találja a játékot. Nagyon fontos számára, hogy értelmet ad valaminek, amit nem ő egyedül hozott létre, a közös alkotás öröme ez.

Negyedik utasítás: „Adjatok címet annak a rajznak, amelyiknek szeretnétek." A rajzos tartalomhoz címet rendelnek, ki melyikhez akarja. Ez is egy kamasz-jellemző. Keresi az értelmét. Belelátja mi is rejtőzködik ott.

Ötödik utasítás: „Rakjuk sorba a múveket, hogy mindegyik jól látható legyen. Válassz egyet, amelyik nagyon tetszik.” Majd: „Most válassz egyet, amelyik érdekes számodra, furcsa.” Ezt követően: „Válassz egyet, amelyik olyan szokványos." Utolsó (mert négy egységben gondolkodom, a csoportlétszám függvényében): „Válassz egyet, amelyiket még egy kicsit kiegészítenél." Ezután következik a tulajdonképpeni alkotás. A kamaszok szelektálhatnak. Érzéseket rendelhetnek az általuk megalkotott, agyoncsócsált, mármár sajátjuknak érzett alkotásokhoz

Hatodik utasítás: „Rendezd sorrendbe a négy rajzot, meséld el e történeted."

Ezután következik a narráció. Az így nyert képek sorozattá rendeződnek és a kamasz egy történetet mond el ezekről.

Ezt fogjuk eljátszani.

Dinamikus technika, a passzívabb tagok is megszólalnak. Több összetevője van, valamihez mindenki hozzászól, vagy cselekszik. Időben jól strukturálható. Egyéni terápiában is használható kevés módosítással, amelyben a terapeuta és a kliens együtt alkot.

Egy kriksz-kraksz mese-részlet: „„... új lakos érkezett. Sajtfejú-kockanadrág. Nagyon furcsának tartották. Nem kommunikáltak vele. Ô sem a többiekkel. Egy nap hangversenyt rendeztek a falu közösségének, és ez a Sajtfejú-kockanadrág is benevezett rá. Első díjat nyert, s azóta az egész vidék szereti és tiszteli." Ez a mese egy vágyteljesító mese, a narrátor elmondhatja, hogy ha kitartó és részt vesz a társai életében, akkor megkapja majd jutalmát, szeretni fogják.

\subsubsection{Hulladékból való alkotás}

Egy hulladékokat tartalmazó doboz került a kör közepére, a kiskamasz valami újat épít ezekből. Ebben a dobozban vannak csipkék, gombok, agyagtörmelékek, kavicsok, ékszerek, textildarabok, hálók, kupakok, színes papírok, múanyag darabkák, apró játékok, buszjegyek, stb. Az alkotáshoz használhatnak ceruzát, filceket, csipeszeket, ragasztót, ollót, túzőgépet. Minden 
csoporttag megkeresi az(oka)t a hulladéko(ka)t, amely(ek)ból valami új tárgyat akar létrehozni. Ennek valami funkciót kell tulajdonítania. Valamit tudnia kell ennek az újonnan létrejött, egyedi mémnek.

Egy kiskorában a családból kiemelt kamasz a következő gépezetet készítette: „Ez egy olyan tojáskeltető gép, hogy amikor a gyilkos tyúkanyó meg akarja enni a tojását, akkor azt, ez a gépezet kimenekíti és csinál belőle kiscsibét." Ezt a mesélőt kiskorában bántotta az édesanyja, őt valóban ki kellett menteni. Nagyon megható, amikor ezt az élményt a szimbólumok szintjén megfogalmazza, és burkolt üzenetként átadja a csoportnak. Amikor ez elhangzik, a jelképeket csak a csoportvezetók értik, de az átélés mindenki részéről mély és katartikus.

\subsubsection{Varázslatokból identitásválasztás}

Ez egy akciócentrikus, cselekvésen alapuló módszer, amit akkor játszhatunk, amikor a gyermekek már elég jól ismerik egymást és a játékszabályokat ahhoz, hogy ne kövessenek el sértést, vagy ne bántódjanak meg akkor, ha egymásról szimbolikus formában ugyan, de "kritikát” mondanak. Az a felhívás, hogy minden csoporttag, minden egyes társát varázsolja el valamilyen tárggyá vagy állattá. A hátukra lapot túzünk, amire felírják, hogy mivé varázsolják azt, aki viseli a lapot. Általában hosszan méricskélik, szemrevételezik azt, akit éppen elvarázsolni készülnek. Ez az a gyakorlat, ami csak többszöri találkozás után végezhető el kamaszokkal, mert kellő tapintatot és a másikról való gondolkodást igényel.

Miután mindenki elvarázsolt mindenkit, leveszik egymás hátáról a lapokat és elolvassák, amivé őket varázsolták. Nagyon vidám és várakozással teli a hangulat, mert mindenki kíváncsi, hogy a másik mit lát benne. Ezt követően, mindazon tárgyak és állatok közül, amivé őket varázsolták ki kell választaniuk azt az egyet, amivel leginkább azonosulni tudnak. Ezt hangosan megmondják, és ennek beöltöznek. Ezt követóen megalkotják előbb szóban, majd a játékban annak a karakterét, amivé változtak. Közös mesélés és az ezt követó játék zárja a találkozást.

\subsection{A módszerek játékba fordítása,} a drámavezetők beavatkozásai, a pszichodramatikus hatás

Amint azt az egyes módszerek bemutatásakor leírtam, minden egyes módszer alkalmazását követően a kitalált történeteket eljátsszuk. A történet elhangzását követően a résztvevők elmondják, hogy melyik történetben játszanának a legszívesebben. A kiválasztott történet eljátszása azzal kezdő- 
dik, hogy a történet szerzője kiválasztja a saját szerepét. Ezután felajánlhat szerepeket az egyes csoporttagoknak. Rövid egyezkedés után mindenki szerephez jut. A csoportvezetók a megmaradt szerepeket kapják. Nagyon fontos része a játék előkészítésének, hogy milyen színhelyeken játszódik majd a cselekmény. Ezek előkészítésében a csoportvezetők segítenek, kérdéseket tesznek fel, felhívják a figyelmet a hiányzó elemekre. (Például egy barlang berendezésekor használják a padokat, textileket, óriás dobozokat; jelezzük, hogy a mesélő szerint tüzet kell gyújtaniuk, és megkérdezzük, ezt hogyan képzelik el a kijelölt/önjelölt barlanglakók.)

A jelmezeket szintén nagy odafigyeléssel, lehetőleg minél kifejezőbb eszköztárból alkotják meg a szereplók. A csoportvezetóknek fontos odafigyelniük arra, hogy a jelmezek kényelmesek legyenek, és ne legyenek balesetveszélyesek (például a túl hosszú, vagy a látásban akadályozó ruhadarabokat a célnak megfelelóen használják a gyerekek). A terep, a kellékek és a jelmezek megalkotását követóen kerül sor a történet eljátszására. Ez három tapssal kezdődik, gyakran villanyoltással. Az eljátszás során a csoportvezetők a saját szerepeiket játsszák. Akkor kérnek nagyobb teret a játék során, ha valamilyen facilitáló elemet kell belevinniük a játékba. Néhány példa arra, amikor a csoportvezetők a saját szerepkörüket bóvítik, esetleg a saját szerepükön kívül egyéb szerepbe bújva segítik a gyermekek játékát:

Amikor valamelyik gyermek magányossá válik a játék során, akkor azonnal társul hozzá valamelyik csoportvezetô, alárendeltként az ő utasítását, rendelkezését kéri.

Amikor valamelyik szereplő nem hajlandó kollaborálni a többivel, akkor valamilyen veszély formájában igyekszik a csoportvezető őt megkörnyékezni. Ezzel rendszerint azt üzeni, hogy egyedül nehéz lesz győznie. A csoport ilyenkor rendszerint összezár a váratlanul megjelenő ellenséggel szemben.

Ha valamelyik szereplő valamilyen embertelen, meg nem engedhető akcióba kezd, akkor a csoportvezetó reszortja, hogy ezt akár a szerepból, vagy új szerep bevitelével, de ha szükséges a felnőtt státuszából megakadályozza. Erre példa a „Félholtig mútét”, gyermekpszichodramatisták kiképzésére készült videofelvétel, amelyben az orvos szerepet vállaló gyermekek azt játszották, hogy a betegnek mútét közben „csak úgy” kidobálják a szerveit. Ekkor Bogdán Mariann, gyermekpszichodráma-vezető belépett, mint az illető beteg felesége, és arra kérte a doktor urakat, hogy mentsék meg az ő szeretett férjét. A doktor urak megígérték ezt és a játék további részében ezen munkálkodtak, sikeresen.

Akkor is a csoportvezető beavatkozása szükséges, ha a gyermek elóéletét ismerve úgy észleli, hogy olyan játékszituáció alakult ki, amivel a jelen helyzetben a kamasz nehezen boldogul, esetleg éppen azért, mert nagyon hasonlít a valós sérüléseinek valamelyikéhez. Ilyen szituáció lehet az például, 
amikor a játék hozta életérzés erős szorongást ébreszt a szerep során: bezártság, bántalmazás, veszteség, gyász vagy egyéb olyan fenyegetettség, amit a kamasz sejtett és elvállalt a szereposztáskor, de az adott szituációban, a játék során nyilvánvalóvá válik, hogy nem képes ezzel egymaga megbirkózni.

A fentiekben csak néhány példát soroltam fel arra vonatkozóan, amikor nagyon résen kell lennie a csoportvezetőknek ahhoz, hogy a játék hatása pozitív legyen, a dráma gyógyító ereje érvényesüljön, nehogy a kamasz éppen sérüljön a kitett tartalmak kapcsán.

Ezeknek a szituációknak a megfelelő kezelése, a csoportvezetők teendői a gyermekpszichodramatisták kiképzése során konkrét példákon keresztül szemléltetésre kerül. Mégis adódhat a gyakorlatban olyan helyzet, amelynek a megoldása emberségünk, józan paraszti eszünk, és saját pszichés egészségünk próbatétele is.

Mivel a csoportok évtizedek óta minden évben újra és újra szerveződnek, egyre több gyermek és kamasz keresi a csoportlehetóségeket, egyértelmú, hogy a dramatikus hatás gyógyító. A gyermekek, kiskamaszok szüleivel minden csoportzárást követően szülőkonzultációt tartunk. Ekkor rendszerint javulásról, a magatartásproblémák megszúnéséről számolnak be. Ahhoz, hogy dramatikus hatásról beszélhessünk, szükséges, hogy a kamasz legalább egy-másfél évig részt vegyen a pszichodráma csoportban.

\section{Zárszó}

A felsorolt kamasz-technikák, módszerek sokkal gazdagabb repertoárját szoktuk bevetni csoportjainkban. Ez egy ízelítő abból, hogy mi mindenre vehetőek rá a fiatalok, és mindenben önmagukat tükrözik, mi dramatisták pedig óket.

A csoportok fóként pedagógiai szakszolgálatoknál, gyermekjóléti szolgálatoknál, gyakran magánvállalkozásokban múködnek. Javasolt lenne a módszer iskolákban, klinikákon, szakambulanciákon való bevezetése. A kamaszok csoportterápiában képesek leginkább kompetenciáik felmérésére, megerősítésére.

Tanulmányomat Kende B. Hanna soraival zárom. „A magukról rossz véleménnyel lévő vagy negatív énképpel élő, illetve problémás gyerekek felismerik saját értéküket, és kiteljesedjenek, amikor azt tapasztalják, hogy a velük foglalkozó felnőttek megbecsülik őket. De nemcsak önmagukat, egymást is megtanulják becsülni és szeretni, sőt, megtanulnak egymásért tevékenykedni. A gyermekpszichodráma alatt ráébrednek, hogy nincsenek egyedül. A korrektív élmény a dramatisták és a csoport tagjaiban kialakuló elfogadó légkörben alakul ki, ahol a gyerek felismeri saját értékeit. Alfred 
Adler szerint minden felnőttnek és gyereknek saját melódiája van. Mi igyekszünk meghallani egyéni melódiáját, és ezzel megkönnyítjük a gyerek számára, hogy meghallhassa önmagát. Figyelünk rá, megpróbálunk vele együtt rezdülni, hogy lehetóvé váljék gátlásainak feloldása, hogy szabadulni tudjon saját magányosságából, és kreativitása felszabaduljon." ${ }^{3}$

\section{Irodalom}

Aichinger, A. (2018). A gyermekpszichodráma a gyermek alapvető pszichológiai szükségletei kielégítésének szolgálatában. (előadás) Nemzetközi Gyermek-és Serdülő Pszichodráma Konferencia, Budapest, 2018. szeptember 28-30.

Buji, F. (2008). Isten halálától az ember haláláig. Ökotáj, 39-40, 11-28. Letöltve: 2019. január 5-én: http:/ / www.okotaj.hu/szamok/41-42/ot41-03.htm

Grawe, K. (2004). Neuropsychotherapy: How the neurosciences inform effective psychotherapy. New York: Psychology Press

Kende, B.H. (2000). Gyermekpszichodráma. Budapest: Osiris Kiadó

Moreno, J.L. (1969). Psychodrama: Action therapy and principles of practice. Vol. 3. New York: Beacon House

Szebeni, V. (2016). Foltokból valóság. Pszichoterápia, 25(1), 54-55.

Winnicott, D.W. (1999). Játszás és valóság - A pszichoterápia klasszikusai. Budapest: Animula Kiadó

\section{Köszönetnyilvánítás}

Köszönöm Kende B. Hanna kiképzőmnek, mesteremnek, hogy megismertetett a gyermekpszichodrámával. Köszönöm, hogy kezdeményezéseim, újításaim mindig bátorította. Köszönöm jelenlegi munkahelyem igazgatóinak, Csibi Enikő főigazgatónak és Bartusné Major Ágnes tagintézmény igazgatónak, valamint valamennyi Kollégámnak támogató, türelmes, segítókész hozzáállásukat a csoportfoglalkozásokhoz. Köszönöm Kissné dr. Viszket Mónika belém vetett bizalmát, újításaim támogatását. Köszönöm dr. Németh Csilla és Drinóczky Viktória kiképző gyermekdráma vezető-szupervízoroknak a Kende Hanna Egyesületre vonatkozó adatok összegyújtését.

\section{Nyilatkozat érdekütközésról}

A szerző ezúton kijelenti, hogy esetében nem állnak fenn érdekütközések.

3 Gyerek-pszichodráma, csoportterápia. Beszélgetés Kende B. Hannával. Letöltve: 2013. 01. 15-én: http:// pszichodrama-irodalom.blogspot.com/2013/01/gyerek-pszichodrama-csoportterapia. html 


\title{
The method of psychodrama with children in Hungary
}

\author{
Adolescent techniques inside of the method
}

\begin{abstract}
SZEBENI, VIOLA
The academic background of my article is Kende B. Hanna's psychodrama training with children. This method keystone relies on Moreno psychodrama. I cover those techniques in detail that change in the presented method, which are the coordinates of the psychodrama with children. The purpose of my comprehensive essay is to introduce the data of the past five years: how many of such kind of groups operated, how many children played in each team, how old they are and what kind of contents a rise regarding their problems. Meanwhile I introduce the groups I consider it essential to review the nature of each groups: to schematize the age groups, furthermore put emphasis on the special, original group features, such as take an example; the adolescent group. The International Conference for Psychodrama with Children and Youth - the same language - symbolic game was held in Budapest (28-30/09/2018; in organization of Kende Hanna Gyermekpszichodráma Egyesület). During the conference the common playing and thinking with Alfons Aichinger formulated the importance of spreading the psychodrama among all children across Hungary. One of the reasons is because it has already gained international fame and nowadays the interest of Kende B. Hanna's method is getting more and more reputed. This essay also presents well-known techniques from conferences, they are proved and played by adolescences. This psychodrama techniques with children are going to be introduced and shared in details. International collaboration also shows the popularity of the techniques. According to data reports the spreading of psychodrama with children as well as the number of new trainers and psychodrama groups are increasing all over the country. However, I signify some missing parts, highlighting that adolescent groups not yet gained satisfactory amount. It occurs quite often that specialized ambulances operate without group therapy. I expand the power equipment and those forums, where the psychodrama with children can be used in the future. We can introduce our techniques and I would like to search new fields where it has not been used yet. In conclusion my aim is to spread Kende B. Hanna's old-established method and introduce it to a wider audience. This essay describes those techniques - how to play with adolescent - which had been already put into practice, but it is high-time to popularize them. However those techniques are used in practice, they are still barely known. Therefore they need to be promoted.
\end{abstract}

Keywords: psychodrama training with children group, adolescent techniques, adolescent groups, international fame 